\title{
II. MEŞRÛTIYYET SONRASI İSTANBUL MEDRESELERİNDE TALEBEYE SUNULAN İÂŞE OLANAKLARI
}

\author{
(1) Talip AYAR ${ }^{\mathrm{a}}$
}

\begin{abstract}
$\ddot{0} \mathbf{z}$
Osmanlı Devleti'nde, kuruluş yıllarından itibaren ilmî ve kültürel kurumların varlığına özen gösterilmiştir. Bu kurumlar fizikî şartları, mimarî özellikleri ve sosyal donatılarıyla temsil ettiği amaca uygun şekilde inşâ edilmiştir. İlmî ve kültürel müesseselerin ilk sırasında yer alan medreseler yapılırken de benzer düşüncelerle hareket edilmiştir. Bir taraftan medreselerin fizikî şartları hazır hale getirilmiş; diğer taraftan eğitim-öğretim faaliyetinin içerisinde bulunacak kişilerin bütün ihtiyaçlarını karşılamaya yönelik alt yapı hazırlanmıştır. Söz konusu ihtiyaçların hemen tamamı vakıflar vasıtasıyla giderilmiştir. Vakıflar, eğitim-öğretimin yanı sıra talebenin iâşe/yeme-içme, ibâte/barınma ve maddî desteklerini/burslarını temin etmiştir. Bu süreçte talebenin iâşe ihtiyacı genellikle, medreselerin civarında yapımı gerçekleștirilen imâretler tarafından karşılanmıștır. Ancak XIX. yüzyılın ikinci yarısından itibaren vakıf gelirleri azalmış, iâşe ihtiyaçlarının karşılanmasında kısıtlamaya gidilmiştir. Dolayısıyla her geçen gün medrese talebesinin, imâretlerden faydalanma olanağı sıkıntılı hale gelmiştir. Bütün bunlara rağmen, İstanbul ölçeğinde düşündüğümüzde, ikisi hariç diğer imâretlerin kapatıldığı II. Meşrûtiyet'in (1908) hemen sonrasına kadar talebenin iâş̧e ihtiyacı, büyük oranda imâretlerden karşılanmıştır. Ancak Osmanlı'nın son dönemlerinde imâretlerin işleyiş̧inde karşılaşılan problemler giderilemeyince ve imâretler kuruluş amaçlarının dışında fonksiyon icrâ etmeye başlayınca, bu kurumların kapatılması yoluna gidilmiştir. Gelinen bu nokta, medrese talebesinin iâşe olanaklarını da etkilemiştir. Dolayısıyla bu makalede, medrese talebesi için geleneksel iâșe olanaklarının değişime uğradı̆̆ı II. Meşrûtiyet sonrası esas alınarak, ne tür bir uygulamaya yer verildiği, yaşanan değişimin talebeye nasıl yansıdığı incelenecektir. Makale hazırlanırken öncelikle arşiv belgelerine, dönemin kroniklerine ve çalışmaya katkı sağlayacak diğer kaynaklara başvurulacaktır.
\end{abstract}

Anahtar kelimeler: İslam Tarihi, II. Meşrûtiyet, İstanbul, medrese, talebe, iâşe.

a Doç. Dr., Bolu Abant İzzet Baysal Üniversitesi, ayartalip@hotmail.com 


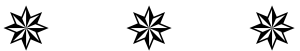 \\ THE SUBSISTENCE/IASE OPPORTUNITIES PRESENTED TO STUDENTS IN ISTANBUL MADRASAS AFTER THE SECOND CONSTITUTIONAL PERIOD}

Since the foundation of the Ottoman Empire, great care has been given to the construction of scientific and cultural institutions. These institutions are constructed in accordance with the purpose they represent with their physical conditions, architectural features and social facilities. The same sentiment has also been shown towards the construction of madrasas, which are at the top of the list amongst these scientific and cultural institutions. While the physical conditions of the madrasas were made ready; on the other hand, the infrastructure has been prepared to meet all the needs of the people involved in the educational activities. Almost all of these needs were fulfilled through waqfs (charity organisations). In addition to education, the waqfs have provided subsistence/iase, shelter/ibate and financial support to the students. The subsistence needs of the students were generally met by the imarets (soup kitchens) located around the madrasas. In addition, in the Ottoman society, where the support for the getting an education was traditionalized, the basic needs of subsistence were sent to the students from the houses near the madrasa. Since the second half of the 19th century, the decrease in the revenues of the waqfs had an impact on the support given to the students. This has restricted the madrasas in meeting the subsistence needs and many unable to provide any food. Therefore, the opportunity to benefit from the imarets were reduced to minimum levels for the madrasa students. Despite all this, from the point of view of Istanbul, until just after the $2^{\text {nd }}$ constitutional period, all but two imarets were closed, and subsistence needs of students were largely met by means of imarets. However, when the problems encountered in the functioning of the imarets in the last periods of the Ottoman Empire could not be solved and the imarets started to function outside the establishment objectives, they were closed. Naturally, this new situation also affected the subsistence resources of the madrasa students.

[The Extended Abstract is at the end of the article.]

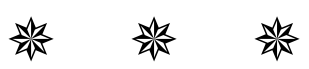

\section{Giriş}

Osmanlı Devleti'nde, eğitim-öğretim faaliyetlerinin yürütüldüğü sıbyan mektepleri ve medreseler vakıflar eliyle kurulmuştur. Bahsi geçen eğitim kurumları çoğunlukla cami, imâret ve türbe gibi değişik 
fonksiyonlardaki binaların bir araya gelmesinden oluşan külliye ${ }^{1}$ tarzı yapılanma içerisinde yerini almıştır. Vakıflar tarafından inşâ edilen ve malî desteği sağlanan medreselerde okuyan talebe, kendilerine tahsis edilen hücrelerde/odalarda kalmış, yemeğini külliyenin imâretinde yemiş ve medresenin bağlı bulunduğu vakıftan maddî desteğini/bursunu almıştır. Külliye içerisinde yer alan imâretler sadece medrese talebesine değil, medresenin eğitim-öğretim kadrosuna, diğer çalışanlarına ve etrafta bulunan yoksullara da hizmet vermiştir. ${ }^{2}$

Dar anlamıyla "fakirlere, medrese sakinlerine çorba ve diğer yiyecekleri pişirip dağıtmaya tahsis edilen hayır kurumu" şeklinde ifade edilen ${ }^{3}$ imâretlerin ortak özelliği, yemek yapma imkânına sahip olmalarıdır. $\mathrm{Bu}$ çerçevede ihtiyaç duyulan sayıda görevli imâretlerde hizmet görmüş, temeli vakıf sistemine dayanan imâretlerden yemek yeme hakkına sahip kişiler istifade etmiştir. Yemek verilecek kişilerin sayısı ve yemeklerin çeşitliliği imâretin bağlı olduğu vakfın maddî imkânlarına göre değişiklik göstermiştir. Genel olarak günde iki ögün yemek verilen imâretlerde, çorba ve ekmek ana yiyecekler arasında yerini almıştır. Pirinç ve bulgur pilavı, yağ, yoğurt, sebzeler ve baharatlarla birlikte yerel tercihler ve mevsimlik yiyecekler ikram edilmiştir. Cuma ve kandil gibi dinî gün ve gecelerde, daha özel yiyeceklerden ve tatlllardan medrese talebesi, cami ve hayrat hademesi, yolcu ve misafirler istifade etmiştir. ${ }^{4}$

Osmanlı'da ilmî ve kültürel müesseselerin inşâsına paralel olarak sosyal amaçlı tesislerin gelişimine özen gösterilmiştir. Yapılan her medresenin yanında ya da etrafında sosyal hayır kurumu olan imâretler vücuda getirilmeye çalışılmıştır. Başta medrese öğrencileri olmak üzere dinî ve ilmî alanda tahsil sahibi olmaya gayret edenleri maîşet sıkıntısından kurtarmak amacıyla büyük fedakârlıklar gösterilmiştir. Bu çerçevede yiyecek-içecek ihtiyaçlarını gidermek için yukarıda bahsedilen gruplar imâretlerden istifade etmiştir. Ancak bütün imâretlerde, herkesten önce mektep ve medrese talebesinin yeme-içme ihtiyaçları giderilmeye

\footnotetext{
${ }^{1}$ Ahmet Vefa Çobanoğlu, "Külliye”, Türkiye Diyanet Vakfi İslâm Ansiklopedisi (Ankara: TDV Yayınları, 2002), 26: 542.

2 Nazif Öztürk, "İmâretler, Geleneksel Yardımlar, Öğrenci Bursları", Türkiye Aile Yıllı̆̆ı (Ankara: Başbakanlık Aile Araştırma Kurumu, 1991), 265, 270.

3 Şemseddin Sami, Kâmûs-ı Türkî, nşr. Ahmed Cevdet (Dersaâdet: İkdam Matbaası, 1317), 2: 950 .

4 Mehmet Zeki Pakalın, Osmanlı Tarih Deyimleri ve Terimleri Sözlüğü (İstanbul: MEB Yayınları, 2004), 2: 61; Amy Singer, "İmârethâneler", Türkler, ed. Hasan Celal Güzel v.dğr., trc. Alim Yılmaz (Ankara: Yeni Türkiye Yayınları, 2002), 10: 484.
} 
çalışılmıştır. ${ }^{5}$ Dolayısıyla Osmanlı coğrafyasında sayıları binlerce olan ve yalnızca İstanbul'da 1859 yılı başında on beșe, II. Meşrûtiyet sonrası ise yirmiye yükselen imâretlerde, öncelikle medrese talebesinin ve diğer ihtiyaç sahiplerinin iâşesi karşılanmıştır. ${ }^{6}$ Fakat II. Meşrûtiyet'in akabinde imâretlerin kapatılması, medrese talebesinin iâșe olanaklarını farklı boyuta taşımıştır. Bu çalışmada, medrese talebesinin geleneksel beslenme usulünün değişime uğradığı II. Meşrûtiyet'in hemen sonrası esas alınarak, İstanbul'daki medrese talebesinin iâşe olanakları belirlenmeye çalışılacaktır.

A. İmâretlerin Kapatılması ve Talebenin Beslenme Durumu

II. Meşrûtiyet'in ilanına kadar medrese talebesi; tıpkı ihtiyaç sahiplerinin, camiler ve diğer hayır kurumlarında çalışanların ve yolcuların yaptığı gibi imâretlerden beslenme ihtiyacını karşılamıștır. Hatta bu süreyi Dersaâdet'teki Imâretlerin Lağvıyla Muhassasâtının Talebe-i Ulûma Tahsisi Hakkında Kanun'un yayımlandığı 19 Rebiülahir 1329/19 Nisan 1911 yılına kadar götürmek mümkündür. ${ }^{7}$

Medrese talebesinin yiyeceği, medreselerin bağlı bulunduğu imâretler vasıtasıyla karşılanmıştır. İmâretlerde öncelikle talebenin istihkakı verilmiş, sonra aralarında ihtiyaç sahiplerinin ve yolcuların bulunduğu diğer gruplara dağıtım gerçekleştirilmiştir. Talebeye, sayılarına göre imâret fırınlarında pişirilen fodula, ${ }^{8}$ çorba, pilav, aşure, zerde ${ }^{9}$ ve bazen de zırva ${ }^{10}$ isimli yemekler verilmiştir. İmâretler sabah namazında açılmış ve sabah derslerinden evvel fodulalar talebeye pay edilmiștir. Ayrıca talebeye, buğday ve arpa unundan veya kırmasından pişirilen çorba ikramı yapılmıştır. Bu çorba belirli bir ölçü çerçevesinde talebeye verilmiş ve imâret dâhilinde taslarla içilmiştir. Dersten çıktıktan sonra ise talebeye yağlı pirinç çorbası

\footnotetext{
5 Ziya Kazıcı, “Osmanlı Devleti'nde İmâret”, Osmanlı, ed. Güler Eren (Ankara: Yeni Türkiye Yayınları, 1999), 5: 44-46.

6 Öztürk, "İmaretler", 266.

7 “Dersaâdet'teki İmâretlerin Lağvıyla Muhassasâtının Talebe-i Ulûma Tahsisi Hakkında Kanun", Düstur (Dersaâdet: Matbaa-i Osmâniye, 1330), 2/3: 353-354.

8 Fodula, yassı pide șeklinde imal edilen ekmeğe verilen isimdir. Fodula daha ziyade imâretlerde, saray mutfağında, İstanbul'daki diğer bazı saraylarda ve yeniçerilere ait fırınlarda pişirilir ve hak sahiplerine dağıtılırdı. Talebenin fodula istihkakı, medresedeki kıdemine ve herhangi bir vakıftan kendilerine fodula dağıtımının şart koşulupkoşulmama durumuna göre değiş̧enlik gösterebilmekteydi. Bkz. Feridun Emecen, "Fodula", Türkiye Diyanet Vakfı İslâm Ansiklopedisi (İstanbul: TDV Yayınları, 1996), 13: 167-170.

9 Zerde, safranla pişirilen bir tür pirinç tatlısıdır. Safranın sarı rengi, pişirilen tatlıya geçtiği için bu isimle anılmıştır. Bkz. Pakalın, Tarih Deyimleri Sözlüğü, 3: 653.

|134| 10 Zırva, imâretlerde pișirilen zerde benzeri tatlıya verilen isimdir. Zırvanın, incir, üzüm, hurma ile pirinç ve şekerden yapıldığı kaynaklarda ifade edilmektedir. Bkz. Pakalın, Tarih Deyimleri Sözlüğü, 3: 659.
} 
verilmiş ve buna bazen de nohut eklenmiştir. Bu çorbayı, arzu edenler imârette içebileceği gibi medresesinde de tüketebilmiștir. Söz konusu çorba ve fodula, talebe arasından seçilen ve kemer adı verilen vazifeli vasıtasıyla medreseye getirilerek dağıtılmıştır. Perşembe günleri her imârette zerde ve pilav; Hamidiye ile Laleli İmâretlerinde pazartesi ve perşembe günleri zerde ve etli pilav yapılmış ve bolca dağıtılmıştır. Bir-iki imârette, bilhassa Beşir Ağa İmâreti'nde ayrıca zırva pişirilmiştir. ${ }^{11}$

Medresede kalan talebenin yiyecekleri imâretlerden dağıtılmakta ise de talebenin ailesi tarafından gönderilen bulgur ve yağ gibi erzak, ilave besin maddesi olarak kullanılmıştır. Zira talebe odalarında bu erzakı pişirmek için ocak ve benzeri imkânlar bulunmuştur. Sözgelimi Dersaâdet medreselerinin tatil olduğu salı günleri, medresede kalan talebeden birkaçı toplanmış, akşam yemeği için aralarında meşhur bir yiyecek olan tel kadayıfı pişirmişlerdir. Hatta et, pilav ve turşu da temin ederek yemeklerini yemişlerdir. Bazen medrese talebesine etrafta bulunan konaklardan kurbanlık koyun gönderilmiş, aşure dağıtılmış ve gıda maddeleri dışında kömür ve kıyafet benzeri malzemelerle de yardım edilmiştir. Özellikle ramazan ayında medresede kalan talebeye iftar yemeği verilmesi, onlara yiyecek gönderilmesi, bayramda hediye takdimi ve maddi destekte bulunulması, talebeye yapılan ikramlar arasında yerini almıştır. ${ }^{12}$

1911 yılında imâretlerde yapılan köklü değişim, medrese talebesinin beslenme olanaklarını değiştirmiştir. 19 Rebiülahir 1329/19 Nisan 1911 tarihinde çıkarılan kanunla İstanbul'da bulunan yirmi adet imâretten ikisi hariç diğerleri kapatılmıştır. Yirmi adet imâretin isimleri ve 1923'lü yıllardaki durumu aşağıdaki tabloda belirtildiği şekildedir.

Tablo 1: Dersaâdet'te Bulunan İmâretler ${ }^{13}$

\begin{tabular}{|l|l|}
\hline İmâretin İsmi & Mevcut Durumu \\
\hline Sultan Fatih & $\begin{array}{l}\text { Mamur/Tamir edilmiş ve talebeye } \\
\text { mahsus }\end{array}$ \\
\hline Sultan Selim & Yıkılmış ve yerine bina yapılmış \\
\hline Sultan Süleyman & Evkâf müzesi \\
\hline
\end{tabular}

11 Müftîzâde, "İstanbul Medreseleri: İâșe I", Sebilürreşad 21/544-545 (12 Temmuz 1339): 190.

12 Abdülaziz Bey, Osmanlı Âdet, Merasim ve Tabirleri, haz. Kazım Arısan, Duygu Arısan, 3. Bs (İstanbul: Tarih Vakfı Yurt Yayınları, 2002), 76-78.

13 Müftîzâde, "İstanbul Medreseleri: İâşe I", 190. 
Talip AYAR

\begin{tabular}{|l|l|}
\hline Sultan Ahmed & Harap \\
\hline Sultan Mustafa (Laleli) & $\begin{array}{l}\text { Mamur/Tamir edilmiş ve fakirlere } \\
\text { mahsus }\end{array}$ \\
\hline Sultan Hamid-i Evvel & Vakıf han \\
\hline Sultan Bayezid & Harap \\
\hline Sultan Osman & Mamur/Tamir edilmiş \\
\hline Ayasofya & Evkâf inşaat ambarı \\
\hline Mihrişâh (Eyüp'te) & Kirada \\
\hline Fatih (Eyüp'te) & Kirada \\
\hline Şehzâde & $\begin{array}{l}\text { Mamur/Tamir edilmiş ve talebeye } \\
\text { mahsus }\end{array}$ \\
\hline Beşir Ağa & Harap \\
\hline Atik Ali Paşa & Münhedim/Yıkı durumda \\
\hline Şehzâde Tâbhânesi & Evkâf matbaası \\
\hline Haseki & Harap ve meşgul \\
\hline Mihrimâh (Üsküdar) & Harap \\
\hline Atik Vâlide (Üsküdar) & Atıl durumda \\
\hline Ahmediye (Üsküdar) & Fakirlere mahsus \\
\hline Koca Mustafa Paşa & Harap \\
\hline
\end{tabular}

Tablo 1'de yer alan imâretlerden Laleli ve Üsküdar'dakiler açık bırakılmış, açık bırakılan imâretler artık fakirlere mahsus olmak üzere hizmet vermiş̦tir. Dersaâdet'te Bulunan İmârâttan İkisinden Mâadâsının Lağvı ile Muhassasâtının Talebe-i Ulûma Tahsîsi Hakkındaki Kanun görüşmeleri Meclis-i Âyan'da yapılırken, imâretlerin kapatılma gerekçelerine temas edilmiştir. Buna göre imâretler, uzun zamandan beri kuruluş amacına uygun şekilde talebeye, fakirlere çok büyük yardımlarda bulunmuş ve hizmet etmiştir. Ancak bir zaman sonra imâretlerin işleyişinde karşılaşılan problemler giderilememiş ve kuruluş amacına muhalif bir fonksiyon imâretlerde görülmeye başlamıştır. Çözüm olarak da açık bırakılacak "iki imâretten mâadâsının muayyenât ve muhassasâtı nakde tahvil olunarak, şimdiye kadar Evkâf Bütçesinden sarf olunan 2 milyon 552 bin 555 
kuruştan mezkûr iki imâret masârifi olan 400 bin kuruş ve muhassasâtı nakde tahvil olunmuş olan mütebâkî imâretlerden fodula ve muayyenât alan ashâb-ı cihâtın vazifelerine muayyenât bedeli olarak icrâ edilecek zamâim karşılı̆̆ı olan mebâliğ ile yalnız 1327 senesinde duâgû fodulalarının teferrûuna karşılık ittihaz olunan 1 milyon 200 bin kuruş tenzil edildikten sonra, mütebâkî meblağ talebe-i ulûma tahsis edilmişti”. ${ }^{14}$ Kısacası kapatılan imâretlerden istifade eden talebeye, fodula alanlara ve vazife gören cihet sahiplerine yardımlar bundan sonra nakdî/para olarak verilecekti.

İmâretlerin kapatılması, herkesin mutabakatıyla gerçekleştirilmiş değildir. İmâretlerin kapatılacağı haberleri henüz yayılmaya başladığında, İslâm medeniyetinin en önemli yapı taşı olan imâretlerin kapatılmak yerine daha mükemmel hale getirilmesinin daha iyi olacağı ifade edilmiştir. Hatta yayılan haberlerin sadece bir şüyûdan/söylentiden ibaret olması temenni edilmiştir. ${ }^{15}$ Keza Meclis-i Âyan'daki müzakereler neticesinde çlkarılan kanun, imâretlerin kaldırılmak yerine ıslah edilmesi, cüzî tasarruflar sebebiyle imâretleri lağvetmenin doğru olmayacağı yönünde görüş beyan edenlerin ve çekimser kalanların bulunduğu oturumda kabul edilmiştir. ${ }^{16}$ Evkâf Nazırı Mustafa Hayri Efendi'nin nezâreti döneminde (1910-1912) ve onun öncülüğünde kabul edilen bu kanunla imâretler özelindeki hayratın zarar gördüğü, Hayri Efendi'nin kararında isabet edemediği veya olumsuz neticeler doğuracağının önceden düşünülemediği zaman zaman dile getirilmiştir. ${ }^{17}$

Talebeye nakdî olarak verilmesi kararlaştırılan miktar, Rûmî 1326/1910 senesi ağustos başından itibaren medreselerde bulunan 5 bin talebeye ödenecek ve aylık yetmişer kuruşun ${ }^{18}$ üstünde olacaktı. ${ }^{19}$ Talebeye dağıtılacak rakam, Meşîhat Makamı ile Evkâf Nezâreti tarafından ortaklaşa düzenlenecek bir kanun vasıtasıyla belirlenecekti. ${ }^{20} \mathrm{Bu}$ çerçevede hazırlanan kanun layihasına/tasarısına göre, on iki senelik medrese tahsilinin birinci safhasını oluşturan medâris-i ibtidâiye talebesine aylık altmış kuruş, ikinci

14 “Dersaâdet'te Bulunan İmârâttan İkisinden Mâadâsının Lağvı ile Muhassasâtının Talebe-i Ulûma Tahsîsi Hakkındaki Kanun Lâyihası", Meclis-i Âyan Zabıt Ceridesi, Devre: 1, İçtima Senesi: 3, İçtima: 52 (4 Nisan 1327/1911), 2: 362-364.

15 "İmâretler", Volkan 1/31 (19 Kanunusani 1324): 3.

16 "Dersaâdet'te Bulunan İmârâttan İkisinden Mâadâsının Lağvı", 2: 364-365.

17 Müftîzâde, “İstanbul Medreseleri: İâșe II", Sebilürreşad 21/546 (19 Temmuz 1339): 210.

18 İstanbul Müftülüğü Meşîhhat Arşivi (MA), Meclis-i Mesâlih-i Talebeye Mahsus Müzekkere Defteri (MMTMMD), nr. 2203: 13 (18 Zilkade 1328/21 Kasım 1910); "Talebe-i Ulûm Muhassasâtına Dair Nizamnâme”, Düstur (Dersaâdet: Matbaa-i Osmâniye, 1330), 2/3: 1, madde 1.

19 “Dersaâdet'te Bulunan İmârâttan İkisinden Mâadâsının Lağvı”, 2: 365.

20 “Dersaâdet'teki İmâretlerin Lağvı”, 2/3: 354, madde 5. 
safhadaki medâris-i tâliye talebesine aylık seksen kuruş ve üçüncü safhadaki medâris-i âliye talebesine aylık yüz kuruş tahsisat/maaş verilecekti. Medreselerde mevcut ve kayıtlı bulunan, imtihanlarda başarılı olan talebe maaş alma hakkı elde edecekti. ${ }^{21}$ Fakat yaptığımız araştırmalar neticesinde söz konusu tasarının kanunlaşmış haline rastlayamadık. Kaldı ki 1914 yılında yayımlanan Islâh-ı Medâris Nizamnâmesi'nin Esbâb-ı Mûcibe Lâyihası'nda belirtildiği üzere "talebe-i ulûm maa't-teessüf endişe-i maîşetten hemen hiçbir zaman tamamıyla kurtulamamış ve ahîren verilen ve yetmiş kuruştan ibaret bulunan tahsisât-ı şehriyye-i cüziyyenin"22 ne kadar olduğu daha net anlaşılmaktadır. Dolayısıyla anladığımız kadarıyla imâretlerin kapatılmasından itibaren beslenme ve benzeri ihtiyaçları karşılamak amacıyla talebeye verilen nakdî ödeme, 1914 yılında yapılan ve ileride üzerinde durulacak olan düzenlemeye kadar yetmiş kuruş olarak gerçekleşmiştir.

\section{B. Yeme-İçme Mekânı Olarak Taâmhâneler}

İlim tahsilini amaç edinen talebenin bütün varlığıyla kendini derslerine vermesi, biraz da maîșet/geçim derdinden kurtulmasına bağlı görülmüştür. Hâlbuki talebenin, hemen hemen hiçbir zaman tam anlamıyla maîşet derdinden kurtulamadığı bir gerçektir. Sonradan verilmeye başlayan aylık yetmiş kuruşluk nakdî ödeme de talebenin ferahlamasına imkân sağlamamıștır. ${ }^{23}$ Esasında bu olumsuz tablonun ortaya çıkması, içinde bulunulan şartlarla doğrudan alakalıdır. Nitekim talebenin bir kısmı harp sebebiyle ve bir kısmı da maîșet darlı̆̆ı dolayısıyla olağanüstü sıkıntı çekmiştir. ${ }^{24}$ Mevcut darlığın bir nebze olsun rahatlatılması düşüncesiyle olsa gerek ki, tatil günlerinde talebenin maîșet tedarikine engel olunmamıștır. ${ }^{25}$ Benzer düşüncelerle atılan bir başka adım ise imâretlerin kapatılmasından sonra talebe için taâmhânelerin açılmasıdır.

\section{Taâmhânelerin Kuruluşu ve İşleyişi}

İmâretlerin kapatılmasıyla talebeye ayrılan tahsisatın nakde çevrilip aylık yetmiş kuruş şeklinde ödenmesi ihtiyaca cevap vermemiştir. Söz

21 "Dersaâdet Medârisinin Sûret-i İdaresi ile Talebe-i Ulûma Verilecek Muhassasât Hakkında Kanun Layihası", Sırât-ı Müstakîm 7/176 (27 Muharrem 1330): 318, madde 23,5 .

22 "Islâh-ı Medâris Nizamnâmesi'nin Esbâb-ı Mûcibe Lâyihası", Dârü'l-hilâfeti'l-aliyye Medresesi (İstanbul: Matbaa-i Ahmed Kâmil, 1330-1333), 7.

23 "Islâh-ı Medâris Nizamnâmesi'nin Esbâb-ı Mûcibe Lâyihası", 7.

24 MA, Meclis-i Mesâlih-i Talebeye Mahsus Müsvedde Varakaları (MMTMMV), nr. 2064: 6 (14 Zilkade 1331/15 Ekim 1913).

25 MA, Ders Vekâleti Defterleri (DVD), nr. 2194, vr. 2b, karar no. 76 (5 Mayıs 1325/18 Mayıs 1909). 
konusu uygulamanın başlangıcından yaklaşık üç buçuk yıllık bir süre geçtikten sonra 1914 yılında talebeye mahsus taâmhâneler kurulmuştur. Üsküdar, Nuruosmaniye, Şehzâde ve Fatih'te kurulan taâmhânelerde talebenin yeme-içme ihtiyacının karşılanması düşünülmüştür. ${ }^{26}$ Bununla birlikte artık talebeye nakdî ödeme yapılmamış, yapılan ödemeler talebenin yeme-içme gibi ihtiyaçlarına mahsup edilmiştir. ${ }^{27}$

Taâmhânelerin kuruluşundan itibaren düzeni temin etmek ve karşılaşılan problemlere tedbir almak için Meşîhat Makamı bünyesinde Şeyhülislâm Mustafa Hayri Efendi'nin (1914-1916) ${ }^{28}$ iradesiyle bir çalışma yürütülmüştür. Çalışmaya Meclis-i Mesâlih-i Talebe azalarının tamamı ve Evkâf-ı Hümâyûn Nezâreti Levâzım Müdürü Haşim Bey katılmıştır. İttifakla alınan ve Şeyhülislâma arz edilen kararlar çerçevesinde; taâmhânelerde verilecek yemek çeşitleri Levâzım Müdüriyeti tarafından belirlenecek ve bir gün evvel baş hademe veyahut imâret memuru tarafından medresenin idare heyeti arasında bulunan dâhiliye müdürüne bildirilecekti. Dâhiliye müdürleri, talebenin, memurların ve hizmetlilerin sayısını, erzakın kilogram hesabıyla miktarını içeren çizelgeyi/tabelayı düzenleyerek yine bir gün önce imâret memuruna teslim edecekti. Dışarıdan Levâzım Müdüriyeti'nin izniyle taâmhâneye kabul edilenlerin sayısı ve bunlara verilecek erzakın miktarı imâret memurunca tayin edilecekti. Erzakın ve gida maddelerinin ambara konulması ve bilahare pişirilmek için ambardan çıkarılması, pişirilmesi, pişirildikten sonra kaplara konulması ve dağıtımı bir heyet huzurunda gerçekleştirilecekti. Her taâmhânede bulunması gereken bu heyette; medreselerde görevli şube müdürlerinden ve talebeden birer kişi ile imâretin memuru, kâtibi, baş hademesi ve aşçıbaşısı bulunacaktı. Gerek dâhiliye müdürlerinin ve gerekse Levâzim ve Mebânî-i Hayriye müfettişlerinin teftiş ve kontrol hakları olacaktı. Her ayın sonunda ambarda düzenli kontroller gerçekleştirilecekti. Bir ay içerisinde Levâzım İdaresi tarafından teslim edilen erzak ile dâhiliye müdürü tarafından hazırlanan çizelge esas alınarak sarf edilen aylık miktar kontrol edilecekti ve her ne olursa olsun dâhiliye müdürleri kontrollerde hazır bulunacaktı. ${ }^{29}$

1914 yılında gerçekleştirilen ıslâh-ı medâris düzenlemesi, Dersaâdet

26 "Islâh-ı Medâris Nizamnâmesi'nin Esbâb-ı Mûcibe Lâyihası", 7; Müftîzâde, "İstanbul Medreseleri: İâşe I", 190; Müftîzâde, "İstanbul Medreseleri: İâşe II", 210.

27 "Islâh-ı Medâris Nizamnâmesi”, Düstur (Dersaâdet: Matbaa-i Âmire, 1334), 2/6: 1327, madde 12.

28 Mustafa Hayri Efendi bu tarihte aynı zamanda Evkâf Nâzırlı̆̆ı görevini de yürütmekteydi ve farklı tarihlerde dört kez Evkâf Nâzırlığı görevine getirilmişti. Bkz. Seyit Ali Kahraman, Evkâf-ı Hümâyûn Nezâreti, 1. Bs (İstanbul: Kitabevi Yayınları, 2006), 62. ${ }^{29}$ MA, MMTMMV, nr. 2073: 30-31, (10 Kanunusani 1331/23 Ocak 1916). 
medreselerini Dârü'l-hilâfeti'l-aliyye Medresesi adıyla tek çatı altında toplamıştır. Bu kapsamda Dârü'l-hilâfeti'l-aliyye Medresesi; tâlî kısm-ı evvel, tâlî kısm-ı sânî ve âlî olmak üzere üç kısma ayrılmıştır. Bununla birlikte âlî kısmının üzerinde Medresetü'l-Mütehassısîn ismiyle bir kısım daha açılmıştır. Medresetü'l-Mütehassısîn kısmının ihtiyacı doğrultusunda şubeler açılmasına izin verilmiștir. ${ }^{30}$ Söz konusu düzenlemenin hemen ardından 1915 yılında yayımlanan talimâtta ise medreselerin idaresi, eğitim-öğretim kadrosu ve medreselere giriş şartları gibi konular ele alınmıştır. Yeni düzenlemeyle, Dârül-hilâfeti'l-aliyye Medresesi'nin idare heyeti, her kısmın umûmî müdürleriyle dâhiliye, sınıf ve şube müdürlerinden oluşacaktır. Sorumluluk itibariyle buradaki idarecilerden her birine çok sayıda görev verilmiştir. Keza görevlerinden bir bölümünü de taâmhânelere yönelik olanları teşkil etmiştir. ${ }^{31}$

Taâmhânelerin düzeni ve işleyişi hakkında değerlendirmeler, ders vekilinin başkanlığındaki Meclis-i Mesâlih-i Talebe'de yapılmış ve karara bağlanmıştır. ${ }^{32}$ Bu bağlamda 17 Kanunusani 1334/17 Ocak 1918 tarihinde bir müzakere gerçekleştirilmiştir. Müzakere neticesinde Meclis, bir önceki yll yayımlanan Medâris-i İlmiye Hakkında Kanun'un on birinci maddesine istinaden ${ }^{33}$ birtakım kararlar almış ve Şeyhülislâma arz etmiştir. Alınan kararlar uyarınca, talebe medreseden taâmhâneye giderken sokaklarda düzenini koruyacak ve her halükarda şube müdürü talebenin yanında bulunacaktı. Talebe her gün belirli saatlerde ve hep birlikte taâmhâneye gidecekti. Talebenin taâmhânede oturacağı masa belirlenecek ve her gün aynı yerde oturması temin edilecekti. Şube müdürleri talebe ile beraber yemek yemeyecek ve kendilerine ayrılan masa başlarından başka yerde oturmayacaklardı. Müdürlerle müderrislerden arzu edenler ve umûmî müdür kâtiplerinden başka hiçbir kimse talebeye ayrılan masalarda ve talebe ile birlikte yemek yemeyecekti. Hatta bu kişiler talebeye ayrllan yemekten de yemeyecekti. Odacı, hizmetli ve dışarıdan taâmhâneye kabul olunanlar, talebeden önce veya sonra ya da talebenin yemek salonuna bitişik kısımda yemeklerini yiyecekti. Dâhiliye Müdüriyeti'nce düzenlenen çizelgelerde talebe, memur ve hizmetli sayısının, erzak kilogram bilgilerinin

30 "Islâh-ı Medâris Nizamnâmesi", 2/6: 1325, 1328, madde 1-2, 19.

31 “Dârü'l-hilâfeti'l-aliyye Medresesine Mahsus Talimâtnâme”, Dârü'l-hilâfeti'l-aliyye Medresesi (İstanbul: Matbaa-i Ahmed Kâmil, 1330-1333), 24-27, madde 1-12.

32 Meclis'in almış olduğu kararların örnek metinleri için “Ekler” kısmına bakılabilir.

33 Maddenin metni șu şekildedir: "Dârü'l-hilâfeti'l-aliyye Medresesi talebesinin taâmı Hazine-i Evkâfça ve kisvesi Hazine-i Mâliyece nizamnâme-i mahsûsları mûcibince i'tâ olunmak beraber...". Bkz. "Medâris-i İlmiye Hakkında Kanun", Düstur (İstanbul: Evkâf Matbaası, 1928), 2/9: 599, madde 11. 
doğru olmasına dikkat edilecekti. $\mathrm{Bu}$ bilgiler çerçevesinde imâret memurlarıyla birlikte ambardan çıkarılacak erzak, kazan başında tartılarak pişirme aşamasına geçilecek ve kullanılan erzak için oluşturulan evrak dâhiliye müdürü tarafından da imzalanacaktı. Medrese talebesinden, memurlardan ve hizmetlilerden başka dışarıdan taâmhâneye devam edenlerin isimlerini içeren bir defterin düzenlenmesi dâhiliye müdürlerinden istenecekti. ${ }^{34}$

Medrese idarelerine gönderilen bu kararların uygulama aşamasında oldukça titiz davranılmıştır. Nitekim sabah, öğle ve akşam yemeklerinin belirlenen saatlerde yenilmesi, ${ }^{35}$ görevlendirilen idareciler nezaretinde taâmhânelere gidilmesi, çizelgelerde isimleri olanların kendilerine ayrılan süreden evvel veya sonra taâmhâneye gelmeleri halinde dikkate alınmayacakları, idarî sorumluluk üstlenen kişilere özellikle hatırlatılmıştır. ${ }^{36}$ Bir defasında, talebenin Fatih taâmhânesine gidişine, yemek esnasındaki davranışına ve medreseye geri dönüşüne dâhiliye, sınıf ve şube müdürleri gereken özeni göstermemiş ve sorumluluklarını tam anlamıyla yerine getirmemişti ve düzenin muhafaza edilmemesi imâret memurlarını ve hizmetlileri müşkül durumda bırakmıştı. Bunun üzerine umûmî müdürlere gönderilen yazıda dâhiliye, sınıf ve şube müdürlerinin görevlerini itina ile yerine getirmeleri hatırlatılmıştı. ${ }^{37}$

Taâmhânelerin kuruluş ve işleyişiyle ilgili bahsettiğimiz hususlar ya medreseler hakkında çıkarılan kanun, nizamnâme ve talimatnâmelerde geçen birkaç madde ile ya da Meclis-i Mesâlih-i Talebe'de alınan kararlar çerçevesinde şekillenmiştir. Keza 10 Cemaziyelahir 1335/2 Nisan 1917 tarihli Medâris-i IIlmiye Hakkında Kanun'da belirtildiği üzere Dârü'l-hilâfeti'laliyye Medresesi talebesinin bir nizamnâme çerçevesinde taâmı/yiyeceği Evkâf Hazinesi'nden ve kisvesi/giyeceği Maliye Hazinesi'nden verilecek olmasına rağmen,38 1919 yılına gelindiğinde henüz bir nizamnâme yani taâmhânelerin işleyişi hakkında kapsamlı yasal düzenleme yapılmamış olması ciddi sıkıntılar doğurmuştur. Dolayısıyla taâmhânelerin idaresi, talebenin yeme-içme düzeni yerli yerinde olmayınca şikâyetler baş göstermiştir. Şikâyetlerin önünü almak ve hepsinden önemlisi taâmhânelerin işleyişini bir nizamnâme çerçevesinde muntazam hale getirmek maksadıyla Şeyhülislâmlık bünyesinde çalışma heyeti

34 MA, MMTMMV, nr. 2088: 31-32 (17 Kanunusani 1334/17 Ocak 1918).

35 MA, MMTMMV, nr. 2087: 55 (8 Kanunusani 1335/8 Ocak 1919).

36 MA, MMTMMV, nr. 2091: 72 (29 Teşrinisani 1335/29 Kasım 1919).

37 MA, MMTMMV, nr. 2094: 115 (19 Teşrinievvel 1335/19 Ekim 1919).

38 “Medâris-i İlmiye Hakkında Kanun", 2/9: 599, madde 11. 
oluşturulmuştur. 11 Kanunusani 1335/11 Ocak 1919 tarihli bir kayda göre umûmî müfettişlerden Receb Efendi'nin, medresenin sahn kısmı Umûmî Müdürü Rıza Efendi'nin ve Evkâf-ı Hümâyûn Nezâreti'nden tayin edilecek iki kişinin katılımıyla oluşacak heyetin, Ders Vekâleti dairesinde haftada iki gün çalışma yürütmesi planlanmıştır. ${ }^{39}$ Fakat bütün uğraşımıza rağmen söz konusu heyetin çalışma yürütüp-yürütmediği, yürüttüyse nasıl sonuçlar elde ettiği hakkında bilgi sahibi olamadığımızı belirtmek durumundayız.

1911 yılında imâretlerin kapatılmasının ardından, talebenin beslenme olanaklarının epeyce güçleştiği aşikârdır. Talebe istihkakının nakde çevrilerek ödeniyor olması, talebenin maîşet derdini çözüme kavuşturmak yerine daha da derinleştirmiştir. Oysa imâretlerin kaldırılmasıyla ilgili Meclis-i Âyan'da dile getirilen görüşlerde talebeye istihkakından daha fazla ödeme yapılacağı ve imâretlerin kapatılmasıyla talebenin bundan zarar görmeyeceği ifade edilmiştir. Ancak anladığımız kadarıyla imâretlerin kapatılması, talebenin düzenli beslenme olanağını ortadan kaldırmıştır. Bunun eksikliği hissedilmiş olsa gerek ki 1914 yılında yeniden taâmhâneler kurulmuştur. Bütün zorluklara rağmen taâmhânelerin kuruluşu ve işleyişiyle talebenin beslenme sıkıntısına az da olsa çözüm üretilmeye çalışılmıştır. Ayrıca taâmhânelerin işleyişine bir düzen kazandırmak için değişik tarihlerde adımlar atılmış ve mevcut işleyişin aksatılmaması adına yoğun çaba sarf edilmiştir.

\section{Taâmhânelerin İşleyişini Bozanlara Uygulanan Yaptırımlar}

Medrese talebesi eğitim-öğretim süresince, medrese ve müştemilatındaki tavır ve davranışlarını, belirlenen esaslar çerçevesinde sergilemiştir. Sözgelimi bir talebe dershane, medrese ve taâmhânelerin demirbaş eşyasıyla arkadaşlarının eşyasına zarar verirse veya onları tahrip ederse verdiği zararı tazmin etmekle yükümlü kılınmıştır. ${ }^{40}$ Bununla birlikte daha geniş ölçekli disiplinsizlikler, yapılan davranışın ağırlığına ve tekrar durumuna göre cezalandırılmıştır. Uygulanan cezalar talebenin uyarılmasından medreseden kaydının silinmesine kadar geniş bir yelpazede seyretmiştir. ${ }^{41}$

Taâmhânelerdeki düzeni bozan ve belirlenen kuralları ihlal eden talebeden, birtakım müeyyidelerle karşı karşıya gelenler olmuştur. Örneğin medrese talebesinden Ahmed Nuri, Salih ve Hasan Hüsnü Efendiler disiplinsiz davranışlarından ötürü uyarılmak durumunda kalmışlardır. Zira

${ }^{39}$ MA, MMTMMV, nr. 2087: 59.

40 “Dârü'l-hilâfeti'l-aliyye Medresesine Mahsus Talimâtnâme”, 31, madde 51.

41 “Dârü'l-hilâfeti'l-aliyye Medresesine Mahsus Talimâtnâme”, 34-35, madde 75-76. 
bu şahıslar beslenme ihtiyaçlarını karşıladıkları taâmhânenin düzenini ihlal etmişler ve ayrıca idare memurlarına karşı başkaldırı niteliğindeki davranışlarda bulunmuşlardır. Yaptıkları sebebiyle öncelikle uyarılmalarına ve olumsuz davranışları devam ettiği takdirde taâmhâneye girmelerinin engellenmesine karar verilmiştir. ${ }^{42}$

Taâmhânelerin asayişini bozan olumsuz talebe davranışlarının neticesi her zaman aynı şekilde sonuçlanmamıştır. Bir defasında Dârü'lhilâfeti'l-aliyye Medresesi kısm-ı âlî birinci sınıf birinci şube talebesinden Hadimli Mustafa Hayri, taâmhânenin düzenini ihlal etmiştir. Ayrıca dâhiliye müdürüne tahkir edici ifadeler kullanması tekdir/kınama cezası almasına neden olmuştur. Söz konusu disiplinsiz davranışlarına, idare tarafından asılan ilanların altına yazı yazmak ve talebeyi idare aleyhine teşvik etmek gibi yenilerini ekleyince, kayıt silme cezasına çarptırılmıştır. ${ }^{43}$

Kayıt silme cezalarında talebenin özel durumu da göz önünde bulundurulmuştur. Örneğin Dârül-hilâfeti'l-aliyye Medresesi tâlî kısm-ı sânî sekizinci sınıf talebesinden Dağıstanlı Hüsameddin Efendi, taâmhânenin düzenini bozduğu ve diğer disiplinsiz davranışları gerekçesiyle kayıt silme cezası almıştır. Ancak talebenin, kayıt silme cezasıyla medreseden uzaklaştırıldığı süre içerisindeki müspet tutumu, medreseden ilişkisi tamamen kesildiği takdirde kendisinin düzensiz bir hayata itilme riski dikkate alınarak kayıt silme cezası affedilmiştir. Hüsameddin Efendi medreseye geri dönmüştür, fakat beslenme ihtiyacını karşıladığı taâmhânedeki kaydı Şehzâde'den Fatih'e alınmıștır. ${ }^{44}$

Talebenin taâmhânelerdeki disiplinsiz davranışlarında farklı sebeplerin etkin olduğu gözlenmektedir. Mesela yemeği beğenmeyerek taâmhâne memuruna karşı olumsuz davranış sergilenmesi, ${ }^{45}$ bir gün önceki ekmek istihkakını isteyen talebenin taâmhâne çalışanlarına fiilî saldırısı, ${ }^{46}$ devamsızlık yaptığı gerekçesiyle yemek hakkı elinden alınan talebenin çıkardığı huzursuzluk, ${ }^{47}$ taâmhânelerin işleyişini bozan disiplinsiz davranışlardan birkaçını oluşturmaktadır.

Taâmhânelerin işleyiş̧ine dair belirlenen kurallar, kuşkusuz sadece talebeyi değil burada çalışan görevlileri de bağlamaktaydı. Çünkü taâmhâne çalışanları, taâmhâneye ve burada dağıtılan yemeklere nezaret etmekle

42 MA, MMTMMV, nr. 2073: 105 (26 Kanunusani 1331/8 Şubat 1916).

43 MA, MMTMMV, nr. 2069: 19; MA, MMTMMV, nr. 2070: 50 (15 Mart 1331/28 Mart 1915).

${ }^{44}$ MA, MMTMMV, nr. 2081: 51, 54 (8 Mart 1331/21 Mart 1915).

45 MA, MMTMMV, nr. 2080: 38 (16 Kanunusani 1332/29 Ocak 1917).

46 MA, MMTMMV, nr. 2091, 137 (9 Kanunuevvel 1335/9 Aralık 1919).

47 MA, MMTMMV, nr. 2091, 193 (15 Kanunuevvel 1335/15 Aralık 1919). 
görevliydi. Talebeye ve taâmhânedeki düzeni teminle görevli şube müdürlerine karşı uygunsuz söz ve davranışlardan sakınacaklardı. Kendilerine yapılan uyarılara kulak vereceklerdi. Bütün bunlara rağmen görevinin gerektirdiği tutum ve davranışların aksine hareket edenlerin taâmhâneyle ilişkisi kesilmekteydi. Nitekim Nuruosmaniye taâmhânesinde, Evkâf Nezâreti Levâzım Müdüriyeti'nce istihdam edilen baş hademe İbrahim Efendi böyle bir akıbetle yüz yüze gelmiști. ${ }^{48}$

Netice itibariyle yaşanan suiistimaller gerekçe gösterilerek 1911 yılında kapatılan imâretlerle sonradan açllan taâmhânelerin benzer sonuçla karşılaşmaması için gereken özen gösterilmeye çalışılmıştır. Doğal olarak taâmhânelerin düzenli işlemesi amacıyla kurallar koyulmuştur. Hem talebenin hem de taâmhâne çalışanlarının, işleyişe büyük oranda olumlu katkı sağladıkları gözlemlense de cezaî müeyyide gerektiren olumsuz örneklerle karşılaşılması bir vakıadır. Alınan önlemlere rağmen yer yer taâmhânelere yönelik şikâyetlerin gündeme gelmesi önlenememiştir.

\section{Taâmhânelere Yönelik Şikâyetler}

Yeme-içme ihtiyacını taâmhânelerden karşılayan talebe, zaman içerisinde hoşnutsuzluklarını dile getirmiştir. Herhangi bir husus için talebenin isteği gündeme geldiğinde, taleplerini iletebilecekleri başvuru yolları açık tutulmuştur. Şöyle ki talebenin her türlü muamelelerinde şube müdürlerine, kayıt ve imtihanlar için sınıf müdürlerine, giyecek ve yiyecek konularında dâhiliye müdürlerine müracaat etmeleri istenmiştir. ${ }^{49}$ Daha sonra bu kapsam biraz daha genişletilerek talebenin herhangi bir hususta başvuru mercii olarak umûmî müdür(lük)ler belirlenmiştir. ${ }^{50}$

Taâmhânelere yönelik şikâyetler, ağırlıklı olarak yemekler ve yemeklerde kullanılan malzemeler çerçevesinde dile getirilmiştir. Sözgelimi Fatih taâmhânesinde yemeklerde kullanılan sade yağın yemek için uygun olmadığı konusunda talebeden şikâyet gündeme gelmiştir. Dile getirilen şikâyet üzerine yapılan tahkikat neticesinde, hakikaten kullanılan yağların karışık olduğu ve talebenin midesine zarar verecek nitelikte bulunduğu tespit edilmiştir. Bu tür malzemelerin yemeklerde kullanılmaması lâş̧e Müdüriyeti'ne bildirilmiştir. ${ }^{51}$

Taâmhânelerin işleyişinde görülen aksaklıklar şüphesiz talebenin dışındaki paydaşlar tarafından da gündeme getirilmiştir. Nitekim

48 MA, MMTMMV, nr. 2082: 21 (9 Mayıs 1333/9 Mayıs 1917).

49 “Dârü'l-hilâfeti'l-aliyye Medresesine Mahsus Talimâtnâme”, 31, madde 49.

50 MA, MMTMMV, nr. 2096: 17 (15 Eylül 1336/15 Eylül 1920).

51 MA, MMTMMV, nr. 2094, 220 (5 Teşrinisani 1335/5 Kasım 1919). 
taâmhânelerde temizliğin, düzenin, talebe disiplininin sağlanmasında dâhiliye, sınıf ve şube müdürleri mesul tutulmuştur. Bu bağlamda talebeye verilmekte olan yemeklerin sağlık açısından uygun olmadığı bir defasında Dâhiliye Müdürü Mahmud Nedim Efendi tarafından dile getirilmiştir. Bu konuda gerçeğin açığa çıkarılması maksadıyla son yirmi günde pişirilen yemeklerin cinsi, türü ve miktarı derhal mercek altına alınmıștır. ${ }^{52}$

Dârü'l-hilâfeti'l-aliyye Medresesi talebesinin yiyeceğini, taâmhânelerin parasını, yakacak ve aydınlatma ihtiyaçları gibi giderlerini karşılayan Evkâf Hazinesi'nin yaşadığı zorluklar, doğal olarak talebenin beslenme imkânlarına da menfi şekilde yansımıştır. Talebenin iâşesine harcanmak üzere Evkâf Hazinesi'ne tahsis edilmesi gereken miktarın genel bütçeden gönderilmemesi ya da eksik gönderilmesi, zaten güç durumda olan Evkâf Hazinesi'ni zora sokmuştur. Keza 1334/1918 yılı bütçesinin taksiminde talebenin iâşesi namına Evkâf Hazinesi'nde kısıtlamaya gidilmesi, bir süredir devam eden sorunun boyutlarını artırmıştır. ${ }^{53}$ Karşılaşılan bu sorun talebeye, mesela Nuruosmaniye taâmhânesine üç gün süreyle ekmek verilememesi, ${ }^{54}$ taâmhânelere gönderilmesi gereken odun ihtiyacının karşılanmaması ve benzeri şekillerde yansımıștır. ${ }^{55}$ Temin edil(e)meyen bu ihtiyaçlar şikâyet olarak sıklıkla gündeme gelmiştir. Sözgelimi taâmhânelerdeki yemek kaplarının odunsuzluk yüzünden soğuk suyla yıkanması ve kaplar yeterince temizlenemediğinden talebenin sağllk şikâyetleri birçok defa ifade edilmiştir. ${ }^{56}$

İfade edilen bilgilerden anlaşıldığına göre taâmhânelerin işleyişi ve orada sunulan beslenme hizmetleri hakkında oluşan şikâyetler, kişisel kusurların yanı sıra daha çok maddî yokluktan kaynaklanmıştır. Ülkenin geneli açısından uzun süredir devam eden ve XX. yüzyıl başlarında iyice açığa çıkan ekonomik sıkıntılar, ülkenin içinde bulunduğu savaş koşulları bu alana da az veya çok tesir etmiştir. Mevcut imkânlar yapılan düzenlemelerle ve sıkı denetimlerle etkin şekilde kullanılmaya çalışılmıştır. Ancak yine de birtakım olumsuzlukların ortaya çımasına engel olunamamıştır.

\section{Taâmhânelerin Denetimi}

Talebenin beslenme olanaklarını sağlıklı hale getirebilmek için taâmhânelerin denetimi birkaç koldan yürütülmüştür. Her şeyden önce

52 MA, MMTMMV, nr. 2086: 189 (30 Kanunuevvel 1334/30 Aralık 1919).

53 MA, MMTMMV, nr. 2101: 292-293 (30 Temmuz 1337/30 Temmuz 1921).

${ }^{54}$ MA, MMTMMV, nr. 2087, 238 (12 Şubat 1335/12 Şubat 1919).

55 MA, MMTMMV, nr. 2089: 82 (3 Mayıs 1335/3 Mayıs 1919).

56 MA, MMTMMV, nr. 2101: 211 (28 Haziran 1337/28 Haziran 1921). 
Talip AYAR

Dârü'l-hilâfeti'l-aliyye Medresesi Talimâtnâmesi çerçevesinde taâmhânelerin temizliği, sıhhî şartlara riayet edilmesi, talebe sayısına göre çizelgelerin oluşturulması ve Levâzım İdaresi'ne verilmesi, yiyecek maddelerinin miktarı, kalitesi, gıda ve sağlık açısından uygunluğu, taâmhâne memurlarıyla hizmetlilerin teftişi, dâhiliye müdürlerinin vazifeleri arasında yer almıştır. Kaldı ki dâhiliye müdürleri, Dârü'l-hilâfeti'l-aliyye Medresesi adına taâmhânenin sorumlusu konumundadır. Bir de taâmhânelerde Evkâf Nezâreti'nin görevlendirdiği memurlar ve hizmetliler bulunmaktadır. Dâhiliye müdürleri, bahsedilen görevlileri, taâmhânelerdeki düzeni, yemeklerde ihtiyaç duyulan gıda miktarını ve sıhhî şartları teftiş etmeye yetkili kılınmıştır. ${ }^{57}$

Taâmhânelerin denetimi ayrıca Dârü'l-hilâfeti'l-aliyye Medresesi Sıhhiye Müfettişliği tarafından gerçekleştirilmiştir. Burada çalışan görevliler, sorumlulukları çerçevesinde denetimlerini yapmış ve gördüğü eksiklikleri rapor haline getirmiştir. Bir defasında teftiş heyetinin hazırlamış olduğu rapordan, son zamanlarda taâmhânelerde verilen yemeklerin sağllk açısından elverişsiz olduğu anlaşılmıştı. Nitekim daha önce peş peşe yapılan benzer şikâyetler üzerine dâhiliye müdürlerince Levâzım Müdüriyeti'ne müracaat edilmişti. Fakat oradan, şikâyetlerin giderileceğine dair olumlu görüş belirtilmişse de herhangi bir adım atılmadığı görülmüştü. Bunun üzerine yaşanan gelişmenin, Şeyhülislâmın iradesi doğrultusunda yazı ile Evkâf Nezâreti'ne bildirilmesi kararlaştırılmıştı. ${ }^{58}$

Evkâf Nezâreti'nin bilgilendirildiği dönemlerde, taâmhânelerde gözle görülür bir düzelme gerçekleşse ve şikâyetler azalsa da birkaç gün sonra yine şikâyetler gündemi meşgul etmiştir. Bu halin devamı, talebenin sıhhatini tehlikeye sokmuştur. Benzer olumsuzlukların giderilmesi amacıyla her gün taâmhânede verilen yemeklerden alınan numunelerin Meşîhat tarafından görülmek üzere buraya gönderilmesi, Meclis-i Mesâlih-i Talebe'de görüşülmüştür. Ayrıca her taâmhânede verilecek yemeklerin gerek miktarını ve gerekse niteliğini belirlemek, diğer hususları gözetmek, ihtiyaç halinde taâmhânelerde veya taâmhânelerin bağlı bulunduğu umûmî müdürlüklerde toplantı gerçekleştirmek üzere bir komisyon kurulması kararlaştırılmıştır. Buna göre komisyonda Meclis-i Mesâlih-i Talebe ile Meşîhat ve Evkâf Nezâreti levâzım kısımlarından ikișer üye yer almıștır. Meclis tarafından, kısm-ı sânî umûmî müdürü Mehmed Fehmi ve müfettiş Mehmed Efendi

57 MA, MMTMMV, nr. 2072: 139 (26 Teşrinisani 1331/9 Aralık 1915); MA, MMTMMV, nr. 2074: 71 (27 Mart 1333/27 Mart 1917).

58 MA, MMTMMV, nr. 2077: 73 (31 Ağustos 1332/13 Eylül 1916). 
komisyon için seçilmiştir. Meşîhat'in Levâzım Müdüriyeti tarafından da belirlenecek iki kişiden sonra neticenin Evkâf Nezâreti'ne iletilmesi uygun görülmüştür. ${ }^{59}$

Taâmhânelerde yapılan denetimlerde karşılaşılan sorunlar farklı şekillerde tezahür etmiştir. Sözgelimi Sıhhiye Müfettişliğince yapılan denetimlerde, talebeye verilmekte olan yemeklerin her gün çorba, etli hububat ve pilavdan ibaret olduğu görülmüş; hiç olmazsa haftada üç gün et ile karışık sebze verilmesinin sağlık açısından daha iyi olacağı belirtilmiştir. 60 Müfettişliğin yaptığı bir başka denetimde ise talebeye verilen yemeklerin sağlık açısından ve beslenme şartları bakımından uygunsuz olduğu, bu durumun talebede sindirim sıkıntısı ve iştahsızlık doğurduğu tespit edilmiştir. ${ }^{61}$

Kuşkusuz taâmhânelerin denetimi sadece verilen yemekler üzerinden gerçekleștirilmemiştir. Taâmhânelerde kullanılan züccaciye malzemeleri, ${ }^{62}$ yemeğe gelen ya da gelmeyen talebe sayısı ${ }^{63}$ gibi birçok konu denetime tabi tutulmuştur. Netice itibariyle medreseler adına taâmhânelerin sorumlusu olan dâhiliye müdürleri ve sıhhiye müfettişleri, taâmhânelerin kontrolünü gerçekleştirmiştir. Denetimlerde yer yer olumsuzluklarla karşılaşılmış ve tespit edilen olumsuzlukların giderilmesi maksadıyla Evkâf Nezâreti'ne başvurulmuştur. Ancak tespiti yapan merci ile sorunu çözecek yerin farklı olması, sorunların çözümünü zora sokmuştur. Zira denetimlerin büyük oranda Meşîhat'in uhdesindeki görevliler tarafından gerçekleştirilmesi ve tespit edilen ihtiyaçların Evkâf Nezâreti'nce giderilecek olması hem sonuç almayı güçleştirmiş hem de koordinasyondan kaynaklı uzayan süreçler talebenin sıkıntılarını artırmıştır. Dolayısıyla ortaya çıkan ikiliğin kaldırılması için İâşe Müdüriyeti'nin kurulduğu anlaşılmaktadır.

\section{Taâmhânelerin Tek Elden Yönetimi: İâşe Müdüriyetinin Kurulması}

Şeyhülislâmlık ile evkâf nazırlığı görevleri aynı kişi tarafından yerine getirildiğinde, taâmhânelerin düzen ve işleyiş̧inde görülen olumsuzluklar asgarî düzeye inmiştir. Taâmhânelerin sorunsuz ya da en az sorunla işletilmesi, talebenin beslenme olanaklarından müspet manada faydalandığ anlamına gelmektedir. Fakat bahsedilen iki farklı görevin iki farklı kişi

59 MA, MMTMMV, nr. 2080: 57-58 (25 Kanunusani 1332/7 Şubat 1917).

60 MA, MMTMMV, nr. 2070: 147 (28 Mart 1331/10 Nisan 1915).

61 MA, MMTMMV, nr. 2086: 117 (19 Kanunuevvel 1334/19 Aralık 1919).

62 MA, MMTMMV, nr. 2092: 132-133 (9 Ağustos 1335/9 Ağustos 1919).

63 MA, MMTMMV, nr. 2094, 224, 228 (6 Teşrinisani 1335/6 Kasım 1919). 
tarafından icrâ edilmesi, koordinasyon problemlerini açığa çıkarmış ve buna bağlı olarak beslenme açısından talebenin mağduriyetine sebep olmuştur. Sözgelimi birkaç teneke bozuk zeytinyağının veya bir çuval fasulyenin değiştirilmesi, Meşîhat ile Evkâf Nezâreti arasında uzun yazışmaları gerektirmiştir. Gün yüzüne çıkan ikiliği ortadan kaldırmak, taâmhânelerin düzenini sağlamak ve talebe hukukunu korumak maksadıyla 18 Şubat 1335/18 Şubat 1919 tarihli mazbata çerçevesinde İâşe Müdüriyeti'nin kurulması kararlaştırılmıştır. Bu düzenlemeye göre taâmhâneler için ayrılan bütçe Evkâf Nezâreti'nden Meşîhat'e aktarılacak, belirlenen usuller çerçevesinde gerçekleştirilen harcamalar her sene sonunda denetlenecekti. Meşîhat ile Evkâf bünyesinden seçilen heyet marifetiyle denetimler gerçekleștirilecekti. Böylece Evkâf Nezâreti'nin, taâmhânelerin idaresi ve mesuliyetiyle alakası kalmamış olacaktı. ${ }^{64}$

Bundan böyle taâmhânelerin yönetim ve düzeni, talebenin yeme-içme işlerinin sevk ve idaresi, Meşîhat bünyesindeki Ders Vekâleti'ne bağlı İâşe Müdüriyeti'nce sağlanacaktır. Tesis edilen birimin tam ismi Dârü'l-hilâfeti'laliyye Medresesi Îâşe Müdüriyeti olacaktır. İâșe müdürünün maiyetinde müfettiş, mümeyyiz, birinci ve ikinci sınıf kâtipler, ambar ve imâret memurları, imâret kâtipleri, aşçllar ve hizmetlilerden oluşan kadro görev yapacaktır.

Yeni kurulan yapı içerisinde iâsşe müdürü, taâmhânelerin genel olarak idaresinden ve buna mukabil bütün işlerden mesul bulunmuştur. Memurların ve kâtiplerin vazifelerine gelince onlar, taâmhânelerin ve ambarların idaresinden sorumlu olmuşlardır. İâşe idaresinde bir de encümen oluşturulmuştur ki, bu encümen Şeyhülislâmlık memûrîn müdürünün başkanlığında toplanmıştır. Ayrıca encümende, ders vekilince seçilecek müfettişlerden ve umûmî müdürlerden birer kişi, fiilen derslere devam eden müderrislerden iki kişi, isteğe bağlı olmak kaydıyla Sıhhiye Müfettişliği'nden belirlenen isim ve Ders Vekâleti başkâtibi yer almıştır. Encümenin yazı işleri, iâşe kalemi mümeyyizi tarafından yerine getirilmiştir.

Encümenin görevlerine gelince onlar, taâmhânelerin faydasına olacak her türlü işi yerine getirmişlerdir. Bin kuruştan fazla olan satın almaları pazarlık suretiyle gerçekleştirmişler ve ödemeleri onaylamışlardır. Levâzım memurluğunun genel olarak işlerini incelemişlerdir. Ambar ve kilerde bulunan erzakı gerek duyulduğunda kontrol etmişlerdir. Senede iki defadan az olmamak üzere ambarların sayımını yapmışlardır. ${ }^{65}$ 
İâşe Müdüriyeti'nin kadro sayısı ve çalışma usulleri belirlendikten sonra ilk iş olarak müdür tayini gerçekleştirilmiştir. Meclis-i Mesâlih-i Talebe'de yapılan müzakereler neticesinde dersiâmlardan Ermenekli Safvet Efendi'nin ismi üzerinde mutabakat sağlanmıştır ve bu ismin iâşe müdürü olabileceği Meşîhat Makamı'na bildirilmiştir. ${ }^{66}$ Şeyhülislâm Haydarîzâde İbrahim Efendi'nin (ö. 1933) arzı ve padişahın onayıyla 1 Mart 1335/1 Mart 1919'da Safvet Efendi iâş̧e müdürlüğü görevine getirilmiştir. ${ }^{67}$

Elbette diğer kadrolar için de gerek lâşse Müdüriyeti'nin kuruluş aşamasında gerekse ilerleyen dönemlerde atamalar yapılmıștır. Sözgelimi iâşe encümen azalarından bir kısmının başka görevlere tayin edilmesi ve bir kısmının da encümen toplantılarına devam etmemesi sebebiyle yerlerine yeni isimler atanmıştır. 12 Temmuz 1335/12 Temmuz 1919 tarihli kayda göre yeni tayin edilen encümen azaları arasında umûmî müfettişlerden Harputlu Mustafa Efendi, umûmî müdürlerden ibtidâ-i dâhil umûmî müdürü Mehmed Âtıf Efendi ve fiilen müderrisliğe devam eden sahn medresesi fıkıh usulü müderrisi Filibeli Ahmed Cevdet Efendi ve felsefe müderrisi Bergamalı Mehmed Zeki Efendi yer almıştır. ${ }^{68}$ Fakat görev değişikliklerinde her zaman kendiliğinden bir boşluğun oluşması beklenmemiștir. Üstlendiği sorumluluğa kayıtsız kalan ve bunu yerine getirmekte acizliği görülen isimler değiştirilmiştir. Fatih taâmhânesinde çalışan Hamdi Efendi ile Şehzâde taâmhânesinde görev yapan Mehmed Efendi böyle bir durumla karşılaşmıştır. ${ }^{69}$

İâşe müdürlüğü görevinde meydana gelen değişikliklerde, o kişinin görev yaptığı süre zarfındaki hesap ve kayıtların incelenmesi, devir-teslim sürecinin mühim bir aşaması kabul edilmiştir. Mesela 2 Zilhicce 1338/17 Ağustos 1920 tarihinde alınan bir karardan öğrendiğimize göre, iâş̧e müdürlüğü görevini devreden Yunus Bahri Efendi'nin idarecilik dönemine ait hesap ve kayıtların incelemesine girişilmiştir. İncelemeyi yapacak komisyonda Sahn Medresesi Umûmî Müdürü Ali Rıza Efendi, Muhasebe Dairesi Müdür Muavini Hayri Efendi ve Dârü'l-hilâfeti'l-aliyye Medresesi müfettiş muavinlerinden ve dersiâmdan Kilisli Tevfik Efendi görev almıştır. Komisyon, kendilerine verilen konuyu derinlemesine incelemek ve ortaya

66 MA, MMTMMV, nr. 2093: 25 (26 Şubat 1335/26 Şubat 1919).

${ }^{67}$ Safvet Efendi'nin atama iradesinde şu ifadeler yer almaktadır: "Medâris-i İlmiye Îașe Müdüriyeti'ne dersiâmdan Ermenekli Safvet Efendi tayin olunmuştur. Bu irâde-i seniyyenin icrâsına Meşîhat memurdur". Bkz. Sadık Albayrak, Son Devir Osmanlı Uleması -İlmiye Ricalinin Teracim-i Ahvali- (İstanbul: Zafer Matbaası, 1981), c. 4-5: vesika 28.

68 MA, MMTMMV, nr. 2092: 27.

${ }^{69}$ MA, MMTMMV, nr. 2099: 385 (14 Eylül 1336/14 Eylül 1920). 
çıkan neticeyi üç nüsha halinde düzenleyeceği mazbatayla Meşihat Makamı'na takdim etmek üzere görevlendirilmiştir. 70

Üzerinde durulan örneğe benzer durum bir başka tarihte yaşanmıştır. Yine iâşe müdürlügü görevinde yapılacak değişim esnasında, önceki yönetim dönemindeki kasa hesabıyla ambar mevcudunun, imâret demirbaş eşyasının ve bunlara ait hesapların incelenmesi; eski ve yeni müdür arasında icrası lazım gelen teslim-tesellüm işleminin tesisi yapılan kontrollerin ardından gerçekleştirilmiştir. ${ }^{71}$

İâşe Müdüriyeti'nin kuruluş aşamasında kadro sayısı ve çalışma usullerinin belirlendiği yukarıda ifade edilmiştir. Ayrıca yine kuruluş aşamasında, bu birimde görev alacak her bir kişinin ne kadar maaş alacağı ve bütçedeki yeri belirtilmiştir. ${ }^{72}$ Dolayısıyla İâş̧e Müdüriyeti'nde çalışanların sayısı ve alacakları maaş tutarları, tabloda belirtildiği şekliyle tatbik edilmiştir.

Tablo 2: İâş̧e Müdüriyeti Çalışanları ve Maaş Tutarları ${ }^{73}$

\begin{tabular}{|l|c|c|}
\hline Görevin Türü & Görevli Sayısı & $\begin{array}{l}\text { Maaş Tutarı } \\
\text { (Kuruş-Her Bir } \\
\text { Görevli İçin) }\end{array}$ \\
\hline İâşe Müdürü & 1 & 300074 \\
\hline Müfettiş & 1 & 1500 \\
\hline Mümeyyiz & 1 & 1500 \\
\hline Birinci Sınıf Kâtip & 2 & 1000 \\
\hline İkinci Sınıf Kâtip & 1 & 800 \\
\hline $\begin{array}{l}\text { Ambar ve İmâret } \\
\text { Memurları }\end{array}$ & 4 & 1000 \\
\hline İmâret Kâtipleri & 4 & 600 \\
\hline Aşçılar & 4 & 1700 \\
\hline
\end{tabular}

70 MA, MMTMMV, nr. 2099: 251.

71 MA, MMTMMV, nr. 2096: 294, 297-298 (6 Teşrinisani 1336/4 Kasım 1920).

72 MA, MMTMMV, nr. 2093: 269 (12 Nisan 1335/12 Nisan 1919).

73 MA, MMTMMV, nr. 2093: 18.

74 Referans alınan yerde, müdürlük için ilave olarak şu şekilde bir açıklama bulunmaktadır: "Müdüriyetin masârif-i zarûriyyesi mukâbili ayrıca beş yüz kuruş ücret-i şehrîsi vardır”. 
II. Meşrûtiyet Sonrası İstanbul Medreselerinde Talebeye Sunulan Iâşe Olanakları

\begin{tabular}{|l|l|l|}
\hline Hademe & 57 & $315^{75}$ \\
\hline Toplam & $\mathbf{7 5}$ & $\mathbf{4 0 0 0 0}$ \\
\hline
\end{tabular}

Tablo 2'de görüldüğü üzere kuruluș aşamasında taâmhâne çalışanlarının da katılımıyla İâşe Müdüriyeti'nde farklı kadrolarda kişiler görev almış ve bunlara bütçenin ilgili kaleminden aylık maaş ödemesi yapılmıştır. Esasında talebenin beslenme ihtiyacının karşılandığı taâmhânelerde böylesine bir düzenlemeye gidilerek İâş̧e Müdüriyeti'nin kurulmasına, yaklaşık aynı döneme tekabül eden bir başka gelişmenin etki ettiğini düşünmekteyiz. Keza aynı tarihlerde özellikle Birinci Dünya Savaşı'nın getirmiş olduğu zorlu şartların aşılması, iaş̧elerin üretiminde ve dağıtımında yaşanan sıkıntıların en aza indirilmesi, hem ordunun hem de sivil halkın beslenmesini temin edecek önlemlerin alınması gibi amaçlarla İaşe Nezâreti kurulmuştur. Zira iâş̧e sıkıntısının görülmesinde savaşın olumsuz etkisi kadar yaşanan kuraklığın, salgın hastalıkların, idarî-malî düzensizliklerin ve bunların sonucunda oluşan kıtlığın büyük etkisi olmuştur. ${ }^{76}$ Dolayısıyla bütün bu güçlükleri aşabilmek gayesiyle devletin İâşe Nezâreti'ni kurarak atmış olduğu önemli ve anlamlı adımın, talebenin beslenme alanına İâşe Müdüriyeti'nin kurulması şeklinde yansıdığını düşünmekteyiz.

Üzerinde durulması gereken bir başka konu ise talebenin yeme-içme sıkıntısını ortadan kaldırmak amacıyla kurulan taâmhânelere ve bu kurumların yönetimindeki ikiliği kaldırmak maksadıyla olușturulan Iâş̧e Müdüriyeti'ne, o dönem getirilen eleștirilerdir. Sözgelimi Müftîzâde, İâşe Müdüriyeti'nin üstlendiği görevi başaramadığını, idarî ve malî imtiyazlar elde etmek için bu birimin kurulduğunu dile getirmiştir. Ayrıca İstanbul medreselerinin idaresini Şer'iye ve Evkâf Vekâleti'nin ilgili birimi (Tedrîsât Müdüriyet-i Umûmiyesi) ele alıncaya kadar taâmhânelerin perişan halde olduğunu kaleme aldığı makalesinde zikretmiştir. ${ }^{77}$ Eleștirilerin haklılık olasılığını bir tarafta tutarak burada görülen olumsuzluğu ya da başarısızlığı bir-iki sebebe indirgemenin, dönemin şartlarını görmezlikten gelmekle eşdeğer olacağını belirtmek durumundayız. Zira ülkenin içinde bulunduğu savaş hali ve kıtlık durumu gibi olumsuz şartlar, talebeye daha iyi beslenme

7557 hademeye ayrılan miktar toplamda 18 bin kuruştur. Dolayısıyla her bir hademeye küsuratıyla birlikte 315 kuruş ödenmiştir.

${ }^{76}$ Cem Doğru, Birinci Dünya Savaşı Döneminde Ekonomide Bir Kurumsallaşma Çabası: İaşe Nezareti, s. 3, 11-20, erişim: 02 Ağustos 2019, http://euniversite.nku.edu.tr/kullanicidosyalari/413/files/Sbm_04_2009.pdf

77 Müftîzâde, “İstanbul Medreseleri: Iâșe II", 211-212. 
olanağı sağlama ihtimalini kısıtlamıştır. Bununla birlikte her ne kadar yapısal reformlar gerçekleştirilse de ortaya çıkan sonuçların istenilen düzeye ulaşamamasında birçok sebebin etki ihtimali unutulmamalıdır. Aksi takdirde çalışmanın başlangıcından bu tarafa anlatılan hususlar ve talebenin maîşet sıkıntısını gidermek için atılan adımlar, gerçeklik düzeyi bakımından zihinlerde soru işareti bırakacaktır.

\section{Sonuç}

İstanbul'da ikisi hariç diğer imâretlerin faaliyetlerine son verildiği döneme kadar medrese talebesi, iâşe ihtiyacını genellikle buralardan karşılamıştır. Bir hayır kurumu olarak inşâ edilen imâretler, hemen hemen her medresenin yanında ya da civarında yapılmıştır. Çünkü Osmanlı'da, ilim tahsil edenlere, toplumun her kesiminden büyük saygı gösterilmiş; dinî ve ilmî sahada tahsil gören talebenin geçim derdinden kurtulması maksadıyla yine herkes tarafından büyük fedakârlıkta bulunulmuştur. Maddî açıdan imkânı yerinde olanlar kurdukları vakıf bünyesinde imâret yaptırmış ve aynı zamanda finansmanını sağlamıştır. İmâretlerden, cami ve hayrat hademesi, fakirler, yolcu ve misafirler iâşe ihtiyacını gidermiştir. Fakat öncelik her daim mektep ve medrese talebesinin olmuştur. Bununla birlikte talebeye, medreselerin etrafındaki yerleşim yerlerinden yiyecek, giyecek ve yakacak gibi ihtiyaç maddeleriyle destek sağlanmıştır. Dikkate değer bu sıcak tavır, ilim tahsil edene gösterilen saygının tezahüründen başka bir şey olmasa gerektir. Ayrıca medrese talebesi, ailesi tarafından gönderilen gıda maddeleriyle de beslenme ihtiyacını gidermiștir. Ancak ailelerin bu anlamdaki desteğinin, medrese talebesinin iâş̧e olanakları bakımından sınırlı düzeyde kaldığını unutmamak gerekir. Dolayısıyla İstanbul'da bulunan medrese talebesi, imâretler kapatılana kadar iâşe ihtiyacını büyük oranda buralardan karşılamış; beslenme açısından kısmî de olsa medrese civarında yaşayanların ve ailelerinin desteğini yanlarında görmüştür.

Uzun yıllar talebeye ve ihtiyaç sahiplerine iâşe olanağı sağlayan imâretler; bir zaman sonra kuruluş amacının dışında işlev görmeye başlayınca kapatılma yoluna gidilmiştir. Esasında o dönem için söz sahibi birçok kesim tarafından, imâretlerin kapatılma yerine ıslah edilmesi önerilmiştir. Fakat karar merciinde bulunanlar imâretlerin kapatılması yönünde tercih belirtmiştir. Sonuçta II. Meşrûtiyet dönemi İstanbul'unda, sayıları yirmiyi bulan imâretlerden ikisi hariç diğerleri kapatılmıştır. Açık bırakılan iki imâret de fakirlere mahsus kılınmıştır. Kapatılan imâretlerden istifade eden hademe ve talebeye ise Evkâf Hazinesi'nden ayrılan bütçeden nakdî ödeme yoluna gidilmiştir. Artık talebeye yemek olarak verilen iâşe 
desteği, aylık yetmiş kuruş şeklinde nakde tahvil edilerek ödenmiştir. Bu meblağın talebeye ulaştırılması, Meşîhat Makamı ile Evkâf Nezâreti arasında yürütülen ortak çalışmayla yerine getirilmiştir.

Talebeye iâş̧e bedeli olarak nakit ödeme uygulaması yaklaşık üç buçuk yll sürmüştür. Bu süre zarfında her ne kadar sorumluk sahibi makamlar tarafından, talebenin maîşet derdinden kurtarılacağı iddia edilse de öngörülen hedef tutturulamamıștır. Talebenin bu konudaki sıkıntısı daha da derinleşmiştir. 1914 yılına gelindiğinde, talebeye yapılan nakit ödemenin mahsubu yoluna gidilmiş; artık ödenen meblağ talebenin yeme-içme ve elbise ihtiyaçlarına sarf edileceği için kendilerine verilmemiştir. Talebenin yeme-içme ihtiyacını karşılamak üzere Üsküdar, Nuruosmaniye, Şehzâde ve Fatih'te taâmhâneler açılmıştır. Taâmhânelerin işleyişi, sorumluları, talebenin buralardan faydalanma biçimleri ilkelere bağlanmıştır. Ayrıca taâmhânelerin düzeni ve işleyişi hakkındaki tüm konular Şeyhülislâmlık'ta ders vekilinin başkanlığında toplanan Meclis-i Mesâlih-i Talebe tarafından görüşülüp karara bağlanmıştır. Netice itibariyle talebeye sağlanan iâşe olanağı, yemek verme şeklinde devam etmiştir.

Diğer taraftan taâmhânelerin kuruluşu, talebenin iâşe ihtiyacının giderilmesindeki sıkıntıları tam anlamıyla ortadan kaldır(a)mamıştır. Gıda, erzak ve maddî bütçe gerektiren ihtiyaçların Evkâf Nezâreti'nce alınması; yönetim ve işleyişin Şeyhülislâmlıktaki ilgili görevlilerce yerine getirilmesi, yönetimsel açıdan ikili yapıyı doğurmuştur. Söz konusu ikili yapı, yönetim açısından zorlukları gündeme getirmiştir. Yaşanan her zorluk, talebeye iâşe olanağının kısıtlanması şeklinde yansımıştır. Alınan kararla, taâmhâneler için ayrılan bütçenin Evkâf Nezâreti'nden Şeyhülislâmlığa aktarılması ve bütün işlemlerin kurulacak İâşe Müdüriyeti tarafından yürütülmesi yoluna gidilmiştir. Bu yapısal dönüşüm, talebenin iâşe olanaklarında biraz daha iyileşmenin önünü açmıştır. Ancak çalışmanın bütünlüğü içerisinde değinilen bütün yapısal reformlar, talebeye sağlanan iâş̧e imkânlarında, mutlak iyinin yakalandığı izlenimini vermekten uzaktır. Bu açıdan yapılan değerlendirmeleri, yaşanılan tarihsel zeminden bağımsız düşünmemek gerekir. Zira ülkenin içinde bulunduğu savaş yılları ve kıtlık durumu, talebeye sunulan iâşe olanaklarının bu kadarına izin vermiştir.

KAYNAKÇA

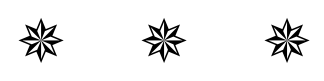

ABDÜLAZIZ BEY. Osmanlı Âdet, Merasim ve Tabirleri. haz. Kazım Arısan, Duygu Arısan,3. Bs. İstanbul: Tarih Vakfı Yurt Yayınları, 2002. 
Talip AYAR

ALBAYRAK, Sadık. Son Devir Osmanlı Uleması -İlmiye Ricalinin Teracim-i Ahvali-. 5 Cilt. İstanbul: Zafer Matbaası, 1981.

ÇOBANOĞLU, Ahmet Vefa. "Külliye". Türkiye Diyanet Vakfi İslâm Ansiklopedisi. 26: 542-544. Ankara: TDV Yayınları, 2002.

"Dârü'l-hilâfeti'l-aliyye Medresesine Mahsus Talimâtnâme”. Dârü'l-hilâfeti'laliyye Medresesi. 24-35. İstanbul: Matbaa-i Ahmed Kâmil, 1330-1333.

"Dersaâdet Medârisinin Sûret-i İdaresi ile Talebe-i Ulûma Verilecek Muhassasât Hakkında Kanun Layihası". Sırât-ı Müstakîm 7/176 (27 Muharrem 1330): 318-319.

"Dersaâdet'te Bulunan İmârâttan İkisinden Mâadâsının Lağvı ile Muhassasâtının Talebe-i Ulûma Tahsîsi Hakkındaki Kanun Lâyihası". Meclis-i Âyan Zabıt Ceridesi. Devre: 1. İçtima Senesi: 3. İçtima: 52 (4 Nisan 1327/1911), 2: 362-365.

“Dersaâdet'teki İmâretlerin Lağvıyla Muhassasâtının Talebe-i Ulûma Tahsisi Hakkında Kanun". Düstur. 2/3: 353-354. Dersaâdet: Matbaa-i Osmâniye, 1330.

DOĞRU, Cem. Birinci Dünya Savaşı Döneminde Ekonomide Bir Kurumsallaşma Çabası: İaşe Nezareti. Erişim: 02 Ağustos 2019. http://euniversite.nku.edu.tr/kullanicidosyalari/413/files/Sbm_04_ 2009.pdf

EMECEN, Feridun. "Fodula". Türkiye Diyanet Vakfi İslâm Ansiklopedisi. 13: 167-170. İstanbul: TDV Yayınları, 1996.

"Islâh-ı Medâris Nizamnâmesi". Düstur. 2/6: 1325-1330. Dersaâdet: Matbaai Âmire, 1334.

“Islâh-ı Medâris Nizamnâmesi'nin Esbâb-ı Mûcibe Lâyihası". Dârü'l-hilâfeti'laliyye Medresesi. 3-8. İstanbul: Matbaa-i Ahmed Kâmil, 1330-1333.

"İmâretler". Volkan 1/31 (19 Kanunusani 1324): 2-3.

İstanbul Müftülüğü Meşihat Arşivi (MA). Ders Vekâleti Defterleri (DVD). 2194.

İstanbul Müftülüğü Meşîhat Arşivi (MA). Meclis-i Mesâlih-i Talebeye Mahsus Müsvedde Varakaları (MMTMMV). 2064. 2069. 2070. 2072. 2073. 2074. 2077. 2080. 2081. 2082. 2086. 2087. 2088. 2089. 2091. 2092. 2093. 2094. 2096. 2099. 2101.

İstanbul Müftülüğü Meşîhat Arşivi (MA). Meclis-i Mesâlih-i Talebeye Mahsus Müzekkere Defteri (MMTMMD). 2203.

KAHRAMAN, Seyit Ali. Evkâf-ı Hümâyûn Nezâreti. 1. Bs. İstanbul: Kitabevi Yayınları, 2006. 
II. Meşrûtiyet Sonrası İstanbul Medreselerinde Talebeye Sunulan Iâşe Olanakları

KAZICI, Ziya. "Osmanlı Devleti'nde İmâret". Osmanlı. Ed. Güler Eren. 5: 44-48. Ankara: Yeni Türkiye Yayınları, 1999.

“Medâris-i İlmiye Hakkında Kanun”. Düstur. 2/9: 598-600. İstanbul: Evkâf Matbaası, 1928.

MÜFTÎZÂDE. "İstanbul Medreseleri: İâșe I". Sebilürreşad 21/544-545 (12 Temmuz 1339): 189-191.

MÜFTîZÂDE. "İstanbul Medreseleri: İâşe II". Sebilürreşad 21/546 (19 Temmuz 1339): 210-212.

ÖZTÜRK, Nazif. "İmâretler, Geleneksel Yardımlar, Öğrenci Bursları". Türkiye Aile Yıllığı. 265-274. Ankara: Başbakanlık Aile Araştırma Kurumu, 1991.

PAKALIN, Mehmet Zeki. Osmanlı Tarih Deyimleri ve Terimleri Sözlüğü. 3 Cilt. İstanbul: MEB Yayınları, 2004.

SINGER, Amy. "İmârethâneler”. Türkler. Ed. Hasan Celal Güzel v.dğr. Trc. Alim Yılmaz. 10: 483-490. Ankara: Yeni Türkiye Yayınları, 2002.

ŞEMSEDDİN SAMİ. Kâmûs-ı Türkî. Nşr. Ahmed Cevdet. 2 Cilt. Dersaâdet: İkdam Matbaası, 1317.

"Talebe-i Ulûm Muhassasâtına Dair Nizamnâme". Düstur. 2/3: 1-3. Dersaâdet: Matbaa-i Osmâniye, 1330.

淡溫 


\title{
THE SUBSISTENCE/IASE OPPORTUNITIES PRESENTED TO STUDENTS IN ISTANBUL MADRASAS AFTER THE SECOND CONSTITUTIONAL PERIOD
}

\author{
(1) Talip AYAR a
}

\section{Extended Abstract}

Since the foundation of the Ottoman Empire, great care has been given to the construction of scientific and cultural institutions. These institutions are constructed in accordance with the purpose they represent with their physical conditions, architectural features and social facilities. The same sentiment has also been shown towards the construction of madrasas, which are at the top of the list amongst these scientific and cultural institutions. While the physical conditions of the madrasas were made ready; on the other hand, the infrastructure has been prepared to meet all the needs of the people involved in the educational activities. Almost all of these needs were fulfilled through waqfs (charity organisations). In addition to education, the waqfs have provided subsistence/iase, shelter/ibate and financial support to the students. The subsistence needs of the students were generally met by the imarets (soup kitchens) located around the madrasas. In addition, in the Ottoman society, where the support for the getting an education was traditionalized, the basic needs of subsistence were sent to the students from the houses near the madrasa. Since the second half of the 19th century, the decrease in the revenues of the waqfs had an impact on the support given to the students. This has restricted the madrasas in meeting the subsistence needs and many unable to provide any food. Therefore, the opportunity to benefit from the imarets were reduced to minimum levels for the madrasa students. Despite all this, from the point of view of Istanbul, until just after the $2^{\text {nd }}$ constitutional period, all but two imarets were closed, and

\footnotetext{
a Assoc. Prof., Bolu Abant İzzet Baysal University, ayartalip@hotmail.com
} 
subsistence needs of students were largely met by means of imarets. However, when the problems encountered in the functioning of the imarets in the last periods of the Ottoman Empire could not be solved and the imarets started to function outside the establishment objectives, they were closed. Naturally, this new situation also affected the subsistence resources of the madrasa students.

Until the imarets were closed, the subsistence needs of the madrasa students were met with meals. However, this practice has been abolished since the mentioned period and financial support to students was introduced. From the beginning of August 1910, it was decided to give a monthly rate of seventy kuruş to the student. This continued until 1914 when taamhane's (eating places) were introduced as the cash payments were not sufficient to provide the students' subsistence needs. With this arrangement made in 1914 , the student would no longer be paid cash, but the payments to be made would be deducted from the subsistence needs of the student. As applied before the imarets were closed, Taamhane's in Üsküdar, Nuruosmaniye, Şehzade and Fatih would provide the student's subsistence needs. Since the establishment of taamhane's, measures were taken to ensure order and eliminate problematic situations. The proceedings were conducted through a commission formed within the structure of the Shaykh al-Islam.

Determination of the kinds of food to be given to a student in the taamhane's designating how many daily meals would be given to people, storage of food and grocery to be cooked and all other operational responsibilities were assigned. In short, all issues regarding the organisation and operation of taamhane's were discussed and settled by the Meclis-i Mesâlih-i Talebe (Student Affairs Council), headed by the lecturer within the structure of Shaykh al-Islam. Care was taken to implement the decisions taken. As a matter of fact, sanctions would be imposed on both the madrasa students and those who did not show the necessary attention from the staff and the responsible people. So much so that the penalties would lead to a cancellation of the madrasa student's enrolment. Although measures were taken requiring heavy sanctions, complaints against taamhane's were frequent. In fact, majority of the complaints regarding the food, heating and lighting expenses were related to Evkaf Hazine (Waqf Treasury) not meeting its obligation to support the taamhane's due to financial difficulties. Likewise, the reduction of the appropriation allocated from the general budget to the Evkaf account necessitated the restriction of the budget for the subsistence and other needs of the student. Eventually, every need that couldn't be met resulted in complaints to the authorities. On the other hand, personal 
shortcomings from the use of existing opportunities were also witnessed. However, complaints from material deprivation were more prominent than others.

In order to eliminate the negativity of the above and make the functioning of the taamhane's and the subsistence opportunities of the students more functional a Food-Supply Office was established in 1919. In the previous practice, food, supplies and material budget requirements of the taamhane's were under Evkaf's administration; while responsibilities such as administration and operation, were fulfilled by the Shaykh al-Islam. This dual structure in practice frequently caused the problem of coordination to occur. For example, the replacement of a purchased and defective food item required long correspondence between the two institutions. As a consequence, every delayed process in order to meet the needs was negatively reflected to the situation of the student. From now on, the budget allocated for taamhane's will be transferred from the Evkaf administration to the Shaykh al-Islam and all proceedings will be carried out by the Iaşe office. Establishment of the Food-Supply Office was aimed at eliminating long procedures, ensuring unity in management and provide the students with better opportunities to meet their needs. However, despite all these structural reforms, it would not be more than optimistic to claim that the most perfect access to the needs of the student was achieved.

The subsistence opportunities of the students in Istanbul madrasas, where we briefly touched above will be examined extensively by resorting to first hand resources as much as possible in this article. The work has been limited to the period shortly after the second constitutional period. The closure of the imarets shortly after the second constitutional period has changed the subsistence opportunities of the students. Therefore, this deep-rooted change is taken into consideration and the subject of the article is based on the second constitutional period. On this date, the closure of the imarets began to be spoken. At the same time, the second constitutional period is accepted as a well-known milestone for many other important changes.

Keywords: Islamic History, Second Constitutional Period, Istanbul, madrasa, students, subsistence/iase.

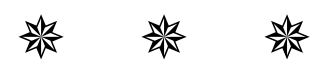

